\title{
Changes in lipid composition of the Antarctic krill Euphausia superba in the Indian sector of the Antarctic Ocean: influence of geographical location, sexual maturity stage and distribution among organs
}

\author{
P. Mayzaud*, E. Albessard, J. Cuzin-Roudy \\ Equipe d'Océanographie Biochimique et d'Ecologie, LOBEPM, URA-CNRS 2077, Observatoire Océanologique, BP 28 , \\ F-06230 Villefranche sur mer, France
}

\begin{abstract}
Lipid content and lipid class composition of Euphausia superba were studied at different levels for populations and individuals sampled in the Indian sector of the Antarctic Ocean. Strong siteto-site variability was recorded which could only partially be related to sex or development stage differences. Three groups of stations could be differentiated. Northern stations were characterized by 'high lipid-high triglyceride' content, western and eastern locations by 'high lipid-high phosphatidyl choline' content and southern areas by 'low lipid-high phosphatidyl ethanolamine/glycolipid' content. Such variability was likely related to advected populations having spent variable lengths of time in the area studied. Lipid content and class among organs were studied in 5 body fractions: abdomen, stomach, digestive gland, gonad and fat body. In absolute terms, the highest concentrations were observed in the ovaries of mature females and the abdomens of the other stages. In relative terms ( $\%$ dry weight), the digestive gland displayed the highest level, except in mature females. Distribution varied with stages, with low triglyceride levels in abdomen tissues of most stages and in the fat body and stomach fractions of subadults. High triglyceride levels were recorded in the other fractions for post spawning females and males, as well as in the fat body fraction for mature females and in subadult gonads. A reverse pattern was observed for the relative content of phosphatidyl choline. Phosphatidyl ethanolamine showed maximum values in the abdomen and the gonad. Glycolipid percentages were maximum in the abdomen, suggesting a structural role. The roles of the different lipid classes are discussed with respect to the function of the organ.
\end{abstract}

KEY WORDS: Krill · Lipids - Spatial heterogeneity - Maturity stage organs

\section{INTRODUCTION}

The role of lipids in Antarctic krill has been the concern of several papers in relation to reproduction (Clark 1980, 1984, Kolokowska 1991, Pond et al. 1995, Virtue et al. 1996), energy storage for overwintering (Quetin \& Ross 1991, Hagen et al. 1996) and trophic interactions (Bottino 1974, Reinhardt \& Van Vleet 1986, Virtue et al. 1993a, b). Krill accumulate lipids mainly as triacylglycerols during the spring and sum-

•E-mail:mayzaud@ccrv.obs-vlfr.fr mer when phytoplankton are abundant (Clarke 1984, Hagen et al. 1996).

Neutral lipids are utilized whenever energy levels exceed food intake. In krill the 2 major energy utilizing events are summer reproduction and winter survival under low phytoplankton conditions. Krill store significant amounts of lipids (Clarke 1984, Hagen et al. 1996), although most studies have concluded that the concentrations are not sufficient to meet the energy requirements during the winter, when food supply is low (Quetin \& Ross 1991, Quetin et al. 1994). However, the contribution of lipids to the overall survival strategy of 
krill appears quite significant (Hagen et al. 1996) and, during the summer period, is channeled mainly into reproductive output.

Krill reproduction takes place over several spawning phases (Cuzin-Roudy 1987, Quetin \& Ross 1991). hence, their reproductive output seems directly related to the richness of the food supply (Ross \& Quetin 1986). Yolk accumulation is characterized by high concentrations of neutral lipids and high levels of triacylglycerols in ovaries of mature females (Clarke 1980, Hagen 1988, Pond et al. 1995). Males do not seem to accumulate neutral lipids in relation to spermatophore production, but various reports have suggested that the energy cost of frequent remating may be high, though distributed differently over time (Virtue et al. 1996). The resulting time integral may represent a significant depletion in lipid content, as reported by Pond et al. (1995).

Contrary to the high levels found in large calanoid copepods, wax esters are not present in krill lipids, and reliance on triacylglycerols as a storage moiety is now well established (Clarke 1980, Hagen 1988, Mayzaud 1997). Reports by Elligsen (1982), Saether et al. (1986), Hagen (1988), and Hagen et al. (1996) suggested that polar lipids, and more specifically phosphatidyl choline (PC), may also serve as storage lipids. The involvement of cell structural components as an energy source has been reported for PC as a source of essential polyunsaturated fatty acids in fish for egg and larval development (see Fraser et al. 1988). This differentiation in the actual role of the lipid classes could provide additional resources during times of increased energy demands.

Our knowledge on the sites of lipid synthesis and catabolism in krill is still limited. Lipid composition has been given for 3 main body fractions, i.e abdomen, digestive gland and mature ovaries (Clarke 1980, Saether et al. 1985, Virtue et al. 1993a), with respect to neutral lipid accumulation. Little is known on the variability of such composition with growth or sexual maturity stage. The potential role of the glyco-lipoprotein complex present in the fat body described by Cuzin-Roudy (1993) remains to be evaluated.

The objective of the present study was to evaluate, for an open-ocean krill population, the influence of exogenous and endogenous factors in the control of lipids during summer. Changes in lipid concentration and composition were investigated at 2 different levels: population and specific organs or body fractions of different growth and maturity stages.

\section{MATERIAL AND METHODS}

Sampling. Euphausia superba were obtained from RMT 8 oblique tows made to a depth of $100 \mathrm{~m}$ during 2 cruises of the RV 'Marion Dufresne' in February 1981 (FIBEX) and February 1994 (ANTARES 2). Positions of sampling stations and cruise track for the first cruise are given in Fig. 1. Samples from the second cruise were obtained at 2 stations $\left(66^{\circ} 41^{\prime} \mathrm{S}, 61^{\circ} 50^{\prime} \mathrm{E}\right.$ and $63^{\circ} 00^{\prime} \mathrm{S}, 70^{\circ} 20^{\prime} \mathrm{E}$ ). Krill were sorted immediately after
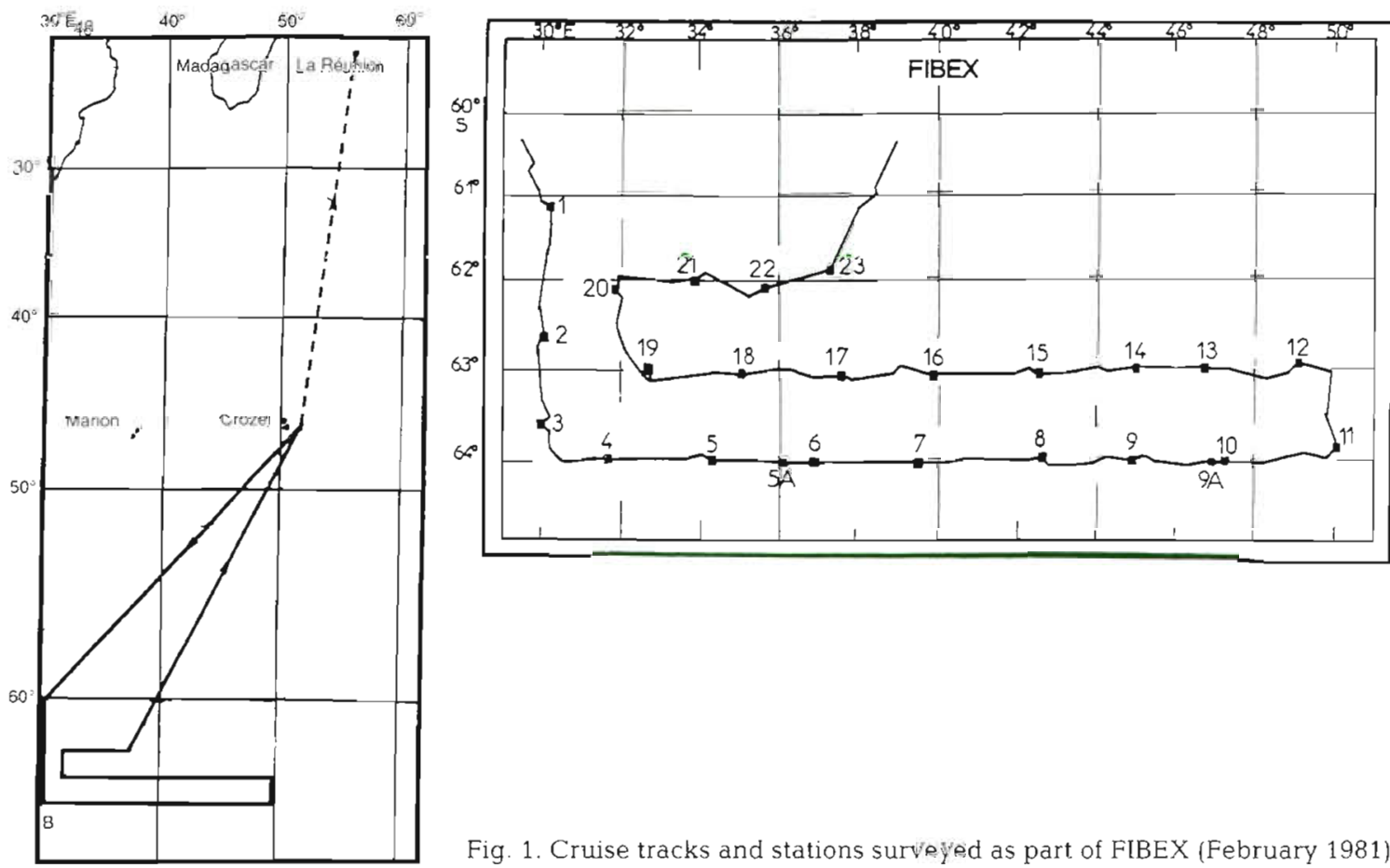

Fig. 1. Cruise tracks and stations surveyed as part of FIBEX (February 1981) 


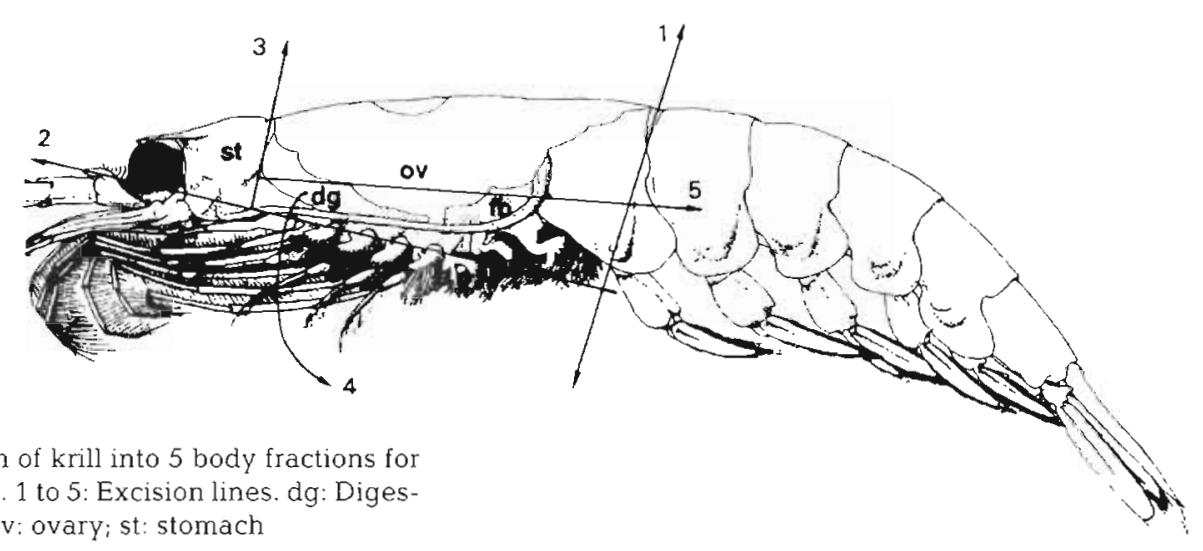

Fig. 2. Euphausia superba. Dissection of krill into 5 body fractions for the separation of the principal organs. 1 to 5: Excision lines. dg: Digestive gland; fb: fat body; ov: ovary; st: stomach

capture, rinsed with distilled water and deep frozen $\left(-80^{\circ} \mathrm{C}\right)$. They were stored at $-70^{\circ} \mathrm{C}$ under nitrogen and transported to France within 4 mo.

Additional samples were collected at different depths for particulate chlorophyll and proteins as descriptors of the trophic environment. Protocols and detailed results can be found in Mayzaud et al. (1985).

Stage determination. For population study (FIBEX), at each station a subset of 20 individual krill were identified to development or sexual stage, measured (BL: standard length 1; Mauchline 1980), weighed (wet weight: WW) and extracted. The rest of the sample was weighed and that part was treated as representative of the whole population. Female were separated into 'maturing' and 'post spawn' categories. Maturing females were recorded as IIIC (Makarov \& Denys 1980).

For the study of specific stages and organs, frozen krill were scored individually for sex, sexual development and maturity (Makarov \& Denys 1980, CuzinRoudy \& Amsler 1991) and measured for body length (BL) while thawing on an ice cold plate under a microscope. Mature female krill $(B L=44.52$ to $58.79 \mathrm{~mm}$ ) with a swollen thorax were staged IIID and SDS 7 (Fig. 2). Spent female krill ( $\mathrm{BL}=43.52$ to $55.70 \mathrm{~mm}$ ) had a small ovary and contracted and irregular lobes. The thoracic cavity was mainly filled with hemolymph. They were scored as SDS 9 rather than IIIA, in order to take into account the ovarian regression which occurs normally at the end of the reproductive season (CuzinRoudy 1987, Cuzin-Roudy \& Amsler 1991). Among the 10 male krill dissected ( $B L=36.75$ to $60.52 \mathrm{~mm}$ ), 4 were mature and 6 had empty ampullae and were scored 'post mature'. Immature young adults $(\mathrm{BL}=38.35$ to $47.04 \mathrm{~mm}$ ) will be referred to as subadults

Separation of main organs. The krill were dissected while thawing to separate either organs or body fractions containing a main organ. During the dissection the specimens were placed on pre-weighted/ pre-extracted filter paper (Whatman 42 extracted in chloroform:methanol 2:1), which collected the fluids originating from each step. Five fractions were sepa- rated (Fig. 2): (1) The abdomen fraction was obtained from excision lines 1 and 2 and contained mostly muscle and cuticle from the abdomen and the various appendages. (2) The anterior fraction containing principally the stomach was next obtained by excision line 3. Minor components were, in decreasing order: eyes, brain ganglia, and cuticle. (3) The digestive gland and the digestive tract were next excised as a whole from the anterior section of the thorax (excision line 4). Whenever the digestive gland was not sufficiently cohesive, recovery was accompanied by leakage of greenish fluid, which was collected on the filter paper, extracted and combined. (4) The fraction containing the gonad was obtained from the dorsal part of the thorax. In mature females the thoracic cavity was overfilled with the swollen ovary and excision along line 5 could not be made without damaging it. The resulting leakage of fluid was collected on the filter paper, extracted and combined. (5) The last fraction contained the fat body, the conjunctive tissue which fills the ventral part of the thoracic cavity and comes in to contact with the ovary (Cuzin-Roudy 1993). A very minor component was the nervous tissue and cuticle.

The wet weight of the 5 organs or body fractions was recorded, and additional specimens were dissected the same way to obtain wet weight/dry weight ratios. In this case dry weight was obtained after oven drying at $60^{\circ} \mathrm{C}$ to constant weight.

Lipid extraction and determination. Entire krill were placed frozen on crushed ice and brought to $0^{\circ} \mathrm{C}$. Size (BL) and fresh weight (WW) were measured before lipid extraction, according to the method of Bligh \& Dyer (1959). Either the extracted lipids were weighed in tarred vials or their concentration was estimated according to Barnes \& Blackstock (1973) but with Euphausia superba lipids as standards instead of cholesterol. Both determinations yielded similar values. The lipid extracts were then placed under nitrogen at $-70^{\circ} \mathrm{C}$ until analysis. Body fractions were extracted immediately after dissection using the same protocol. 
Lipid classes were quantified after chromatographic separation coupled with FID detection on a Iatroscan Mark III TH 10 (Ackman 1981). Total lipid extracts were applied to chromarods SIII using microcapillaries (1 $\mu 1)$ and analyzed in duplicate. Neutral lipids were separated using a double development procedure with the following solvent systems: n-hexane:benzene:formic acid 80:20:0.5 (by volume) followed by n-hexane: diethylether:formic acid 97:3:0.5 (v/v). Glycolipids were separated according to Hirayama \& Morita (1980) with chloroform:ethyl acetate:acetone:methanol:acetic acid: $\mathrm{H}_{2} \mathrm{O}$ 60:12:15:16:3:3 (v/v). Phospholipids were separated with chloroform:methanol: $\mathrm{H}_{2} \mathrm{O}$ 65:35:4 (v/v). Individual calibration of rods was achieved with commercial standards according to Ackman (1981). Using the solvent system indicated, all listed lipid classes, and in particular free fatty acids, were separated and accounted for.

To validate the Iatroscan separation and identification, neutral and polar lipids were further isolated on a preparative scale by column chromatography on silica gel (Bio-Sil HA, minus 325 mesh). The neutra]. lipid fraction was eluted with 6 column volumes of chloroform, the acetone mobile compounds were eluted with 4 volumes of acetone and the phospholipids were eluted with 6 volumes of methanol. All operations took place under nitrogen. Each fraction collected was further separated by thin-layer chromatography (TLC) on pre-coated silica gel plates (Analtech, Uniplate) and developed with hexane:diethylether:acetic acid 80:20: $1.5(\mathrm{v} / \mathrm{v})$ for neutral lipids, or chloroform:methanol. aqueous ammonia 85:30:1 (v/v) for glycolipids, and chloroform:methanol:acetic acid: $\mathrm{H}_{2} \mathrm{O}$ 25:15:4:2 (v/v) for polar lipids. Lipid classes were visualized using dichlorofluorescein and identification was achieved by comparison with standard mixtures. Specific detection of phospholipids and glycolipids by TLC was made with molybdenum blue and diphenylamine reagents (Stahl 1969). Each of these lipid classes was then applied to chromarods SIII and developed as previously to confirm both identification and retention times of the peaks recorded with total extract.

No attempt was made to hydrogenate the samples (Shantha \& Ackman 1990) because no evidence of subfractionation effects due to the variety of fatty acids could be detected. As recently shown by Miller et al. (1998), the use of commercial standards resulted in an underestimate of the actual concentration of triglycerides but without changes in the shape of the FID response.

Data analysis. The allometric relations for the different maturity stages ( $W W=a B L^{b}$ ) were computed after log-log transformation and model I regression (Sokal \& Rohlf 1981).

One- and two-factor variance analyses were performed for total lipids as well as lipid classes. Multiple comparisons of means were achieved using the Tukey test procedure. Comparison of linear regression equations was achieved by covariance analysis. All the above procedures were carried out according to Sokal \& Rohlf (1981). Systat 7.0 statistical package was used for all bivariate tests (Wilkinson 1996).

Principal component analysis (PCA) was performed after arcsine transformation to normalize percentage data. Details on the method and means of interpretation are given in Mayzaud et al. (1989). To facilitate the representation of the factor scores structure, an ascending hierarchical clustering method was used (Lebart et al. 1995) to group those observations which displayed maximum similitude and to produce a number of classes best represented in a dendrogram.

Correspondence analysis (Benzecri 1969, Gower 1987) was performed on a data matrix transformed to relative frequencies and scaled so that each row (or column) can be viewed as a row (or column) of conditional probability distribution. Distances between profiles were computed with $\chi^{2}$ metrics. This distance gives symmetry to the 2 sets of data so that each factorial axis of the cloud of variables corresponds to a factorial axis of the cloud of observations. Thus, it was possible to represent simultaneously descriptors and observations on the plane defined by the factorial axes. Interpretation and representation followed that described above for PCA.

Computation of multivariate tests was made using the SPAD 3.0 software (Lebart et al. 1995)

\section{RESULTS}

\section{Size, weight and lipid relationships}

The size, wet weight and lipid content of the 4 categories of krill collected during the FIBEX cruise are summarized in Table 1. Subadults displayed the smallest size and weight of the 4 groups, while males and females showed similar size ranges ( 31 to $44 \mathrm{~mm}$ ) but slightly different wet weight distribution. Mean values were not statistically different ( $t$-test, $p<0.05$ ) but ranges suggested a trend towards maturing females and males being heavier $(0.57$ to $1.28 \mathrm{mg}$ and 0.4 to $1.21 \mathrm{mg}$, respectively) compared to post spawn females. Lipid content relative to wet weight suggested maximum accumulation in maturing females $(3.3 \%)$. Males tended to show minimum lipid content although the high variability in this case prevented statistical significance.

The wet weight (WW) relationships with size or lipid content were established for each stage present in the samples collected, i.e. subadults, males and females. The $\log \log$ regressions between size and weight 
Table 1. Euphausia superba. Range and mean values of krill size, wet weight and total lipid content (\% wet weight) of specific maturity stages of individuals collected during FIBEX. $n=$ number of individuals analyzed

\begin{tabular}{|lccccccc}
\hline Stage & $\mathrm{n}$ & $\begin{array}{c}\text { Size } \\
\text { range } \\
(\mathrm{mm})\end{array}$ & $\begin{array}{c}\text { Mean } \\
\text { size } \\
\pm \mathrm{SD}\end{array}$ & $\begin{array}{c}\text { Wet weight } \\
\text { range } \\
(\mathrm{mg})\end{array}$ & $\begin{array}{c}\text { Mean wet } \\
\text { weight } \\
\pm \mathrm{SD}\end{array}$ & $\begin{array}{c}\text { Total lipid } \\
\text { range } \\
(\% \text { wet wt) }\end{array}$ & $\begin{array}{c}\text { Mean total } \\
\text { lipid } \\
\pm \text { SD }\end{array}$ \\
\hline Subadults & 33 & $23-35$ & $29.7 \pm 3.1$ & $0.20-0.59$ & $0.37 \pm 0.12$ & $1.1-4.7$ & $2.9 \pm 0.9$ \\
Males & 54 & $31-43$ & $37.1 \pm 2.6$ & $0.40-1.21$ & $0.74 \pm 0.18$ & $0.7-5.0$ & $2.2 \pm 0.9$ \\
Maturing females & 14 & $35-44$ & $39.3 \pm 2.6$ & $0.57-1.28$ & $0.93 \pm 0.22$ & $1.6-4.8$ & $3.3 \pm 0.8$ \\
Post spawn females & 20 & $35-42$ & $38.1 \pm 1.8$ & $0.53-0.96$ & $0.74 \pm 0.11$ & $1.1-4.8$ & $2.8 \pm 1.2$ \\
\hline
\end{tabular}

(Fig. 3) appeared to be similar for all 3 stages (slope: $F_{2,118}=2.07$; intercept: $F_{2,120}=0.26$ ) corresponding to an overall regression equation of:

$$
\begin{gathered}
\log W W=-0.08+3.12 \log B L \\
\left(r=0.967, F_{1,124}=1779, p<0.0001\right)
\end{gathered}
$$

Relationships between WW and total lipids or phospholipids (Fig. 3) were all significant $(p<0.008)$. The regressions for male individuals showed slopes or inter- cepts different from the other 2 stages. Males and females appeared to accumulate lipids and phospholipids at a similar rate (slope: $F_{1,85}=0.272$ ) but with a lower intensity (intercept: $F_{1,86}=14.25$ ) for a given size in males. Triglycerides illustrated a different pattern of changes with only 2 significant regressions, those for subadults (n $=33, r=0.673)$ and females $(n=33, r=0.556)$, which showed a significant difference in intercept $\left(F_{1,66}=5.54\right)$ but not in slope $\left(F_{1,65}=0.04\right)$. In these 2 stages, triglyc-
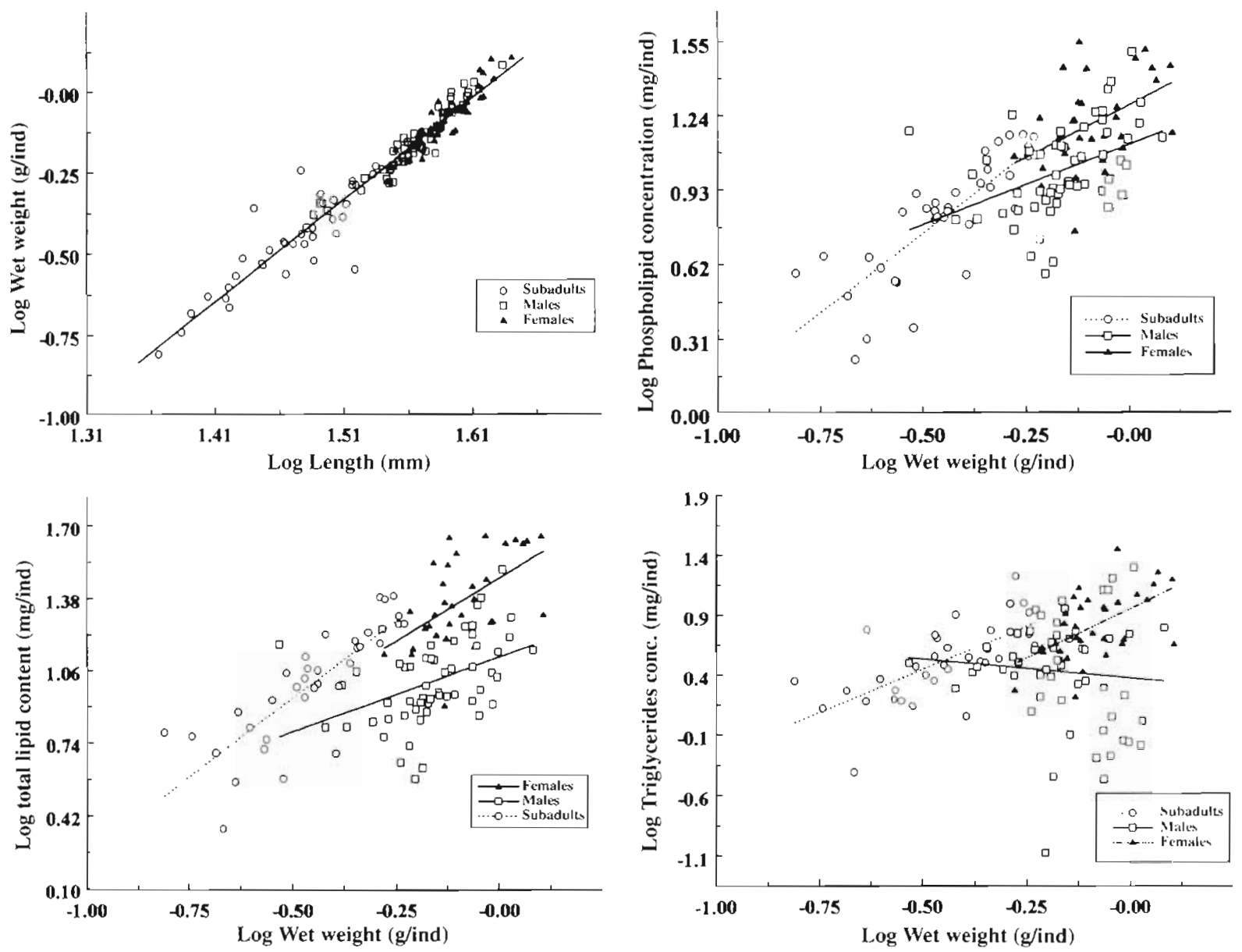

Fig. 3. Euphausia superba. Log-log regressions, for the 3 major developmental stages, between wet weight and body length and between wet weight and total lipid, phospholipids and triglycerides content 
erides were accumulated at a similar rate but with a lower intensity in females than in subadults. The lack of correlation for the male data set was to a large extent associated with an increased variance, with low concentrations in the medium to large size range.

\section{Lipid content and spatial heterogeneity}

To test the relative influence of geographical location and biological descriptors we conducted an analysis of variance. The relative lipid content recorded at the population level was significantly related to stage distribution and location of sampling but not to size or weight (Table 2). The overall mean lipid percentage (2.6\% wet weight) can be divided into 2 groups of stations, irrespective of the sex or stage composition ( $t$ test $=7.65, \mathrm{df}=48, \mathrm{p}<0.0001$ ): (1) those north and west of the grid (Stns 2, 3,17, 18, 19, and 23) and those to the extreme southeast (Stns 9A and 10) with high concentrations (mean value: $3.1 \%$ wet weight), and (2) those from the central and southern part of the grid (Stns 5, $5 \mathrm{~A}, 6,9$, and 11 ) with low concentrations (mean value: $1.9 \%$ wet weight).

Over the spatial grid surveyed during FIBEX, a relatively complex pattern of lipid classes was observed for
Table 2. Analysis of variance for the lipid distribution of Euphausia superba as \% wet weight over the FIBEX grid of stations

\begin{tabular}{|lrrrrr|}
\hline $\begin{array}{l}\text { Source of } \\
\text { variation }\end{array}$ & $\begin{array}{c}\text { Sum of } \\
\text { squares }\end{array}$ & df & $\begin{array}{c}\text { Mean } \\
\text { squares }\end{array}$ & F-ratio & $\begin{array}{c}\text { Signif- } \\
\text { icance } \\
\text { level }\end{array}$ \\
\hline $\begin{array}{l}\text { Main effect } \\
\quad \text { Station }\end{array}$ & 36.33 & 12 & 3.03 & 3.99 & 0.0000 \\
$\quad$ Stage & 16.81 & 3 & 5.61 & 7.39 & 0.0002 \\
$\begin{array}{l}\text { Covariates } \\
\quad \text { Size }\end{array}$ & 0.28 & 1 & 0.28 & 0.37 & 0.553 \\
$\quad \begin{array}{l}\text { Weight } \\
\text { Residuals }\end{array}$ & 0.06 & 1 & 0.06 & 0.07 & 0.789 \\
Total (corrected) & 144.64 & 123 & & & \\
\hline
\end{tabular}

the different growth and maturity stages. Both structural polar lipids and reserve triglycerides displayed positive linear relationships with total lipids, suggesting that part of the polar lipids acted as reserve lipids (Fig. 4). Interestingly, the relationship significantly differed with the stage considered. A covariance analysis of the various regressions indicated that regressions for polar lipids showed a trend for increasing slopes $(p<0.05)$, with subadults $(r=0.498)<$ male $(r=0.579)$

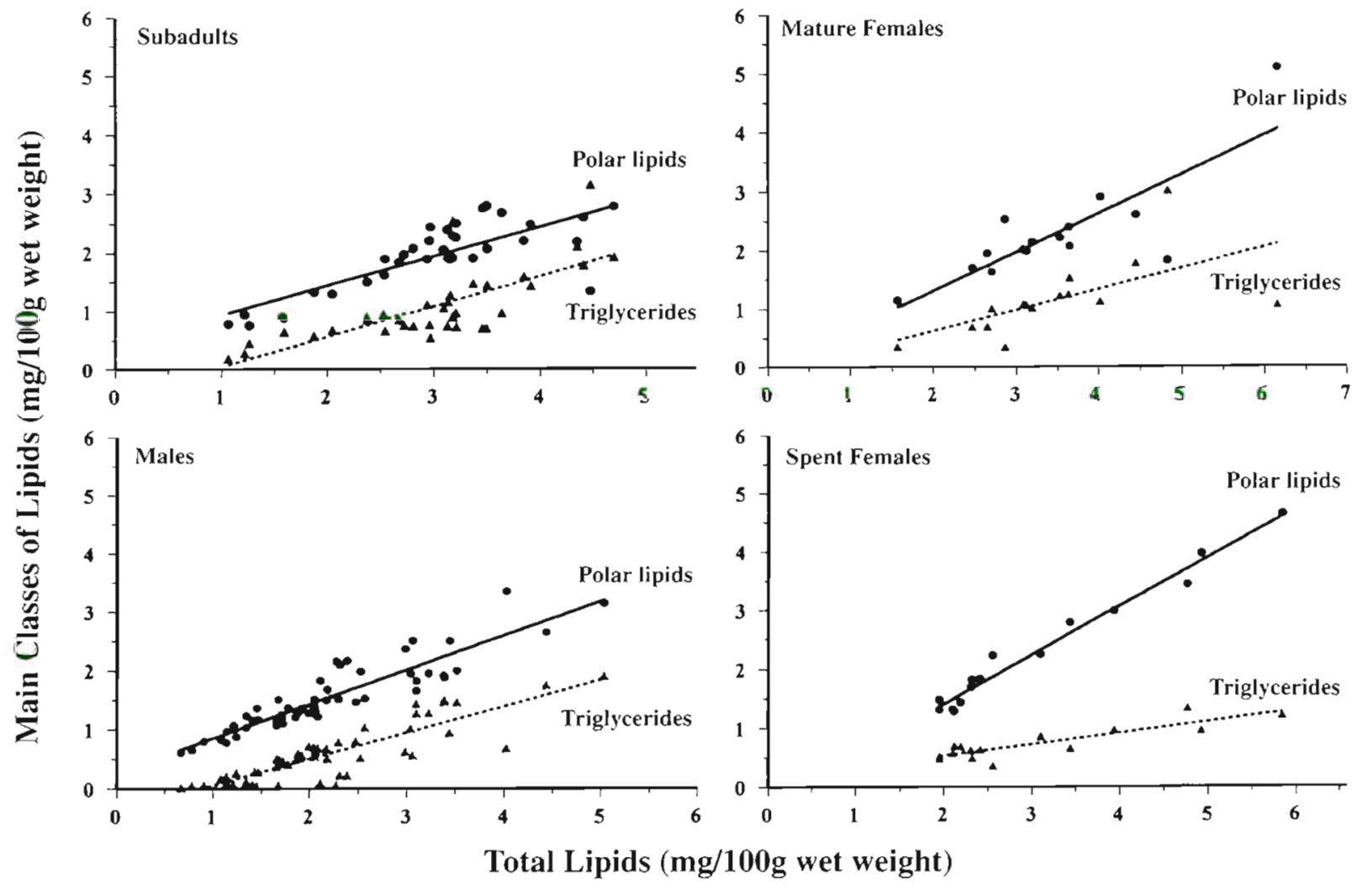

Fig. 4. Euphausia superba. Linear regressions between total lipid content and lipid classes for sexual and developmental stage 
$<$ mature females $(\mathrm{r}=0.659)<$ spent females $(r=0.802)$ and the reverse for triglycerides. Within a given stage, polar lipid and triglyceride relationships were significantly different for males and spent females $\left(F_{1,105}=5.76\right.$; $F_{1.36}=89.95$, respectively) but not for subadults and mature females $\left(F_{1,67}=\right.$ 0.07 and $F_{1,26}=2.74$, respectively).

The spatial structure was analyzed using multivariate correspondence analysis. The factorial plane defined by the first 2 axes accounted for $97.5 \%$ of the total variance. The first and second axes were respectively related to the richness in triglycerides and phosphatidyl choline (Fig. 5). Grouping of stations, based on proximity analysis, showed 3 major clusters, which comprised (1) those stations with high proportions of triglycerides in the total lipids, located in the northern part of the grid (Stn 23 at $62^{\circ} \mathrm{S}$; Stns 17 and 19 at $\left.63^{\circ} \mathrm{S}\right)$, (2) those stations with a high proportion of phosphatidyl choline in total lipids, located at both the western and eastern edges of the grid (Stns 2, 3 and 11), and (3) those stations with high percentages of structural components (phosphatidyl ethanolamine, glycolipids and to a minor extent phosphatidyl choline), in the southern part of the grid (Stns 5A, 6, 9 and $9 \mathrm{~A}$ at $64^{\circ} \mathrm{S}$ ) (Fig. 5).

\section{Distribution of lipids in body fractions and organs}

The respective contribution of the different fractions and organs to the lipid composition of Euphausia superba was studied for different development and maturity stages: subadults, males, mature females and spent females.

The mean sizes of the specimens dissected and the dry weight of the different fractions are presented in Table 3. Size varied over a relatively small range ( 42 to $51 \mathrm{~mm}$ ) and was chosen so that variability around mean size remained more or less constant. In terms of dry weight, if the mature females, for which the heaviest fraction was the ovary, are not included, the abdomen represented the largest body component. The other fractions and organs
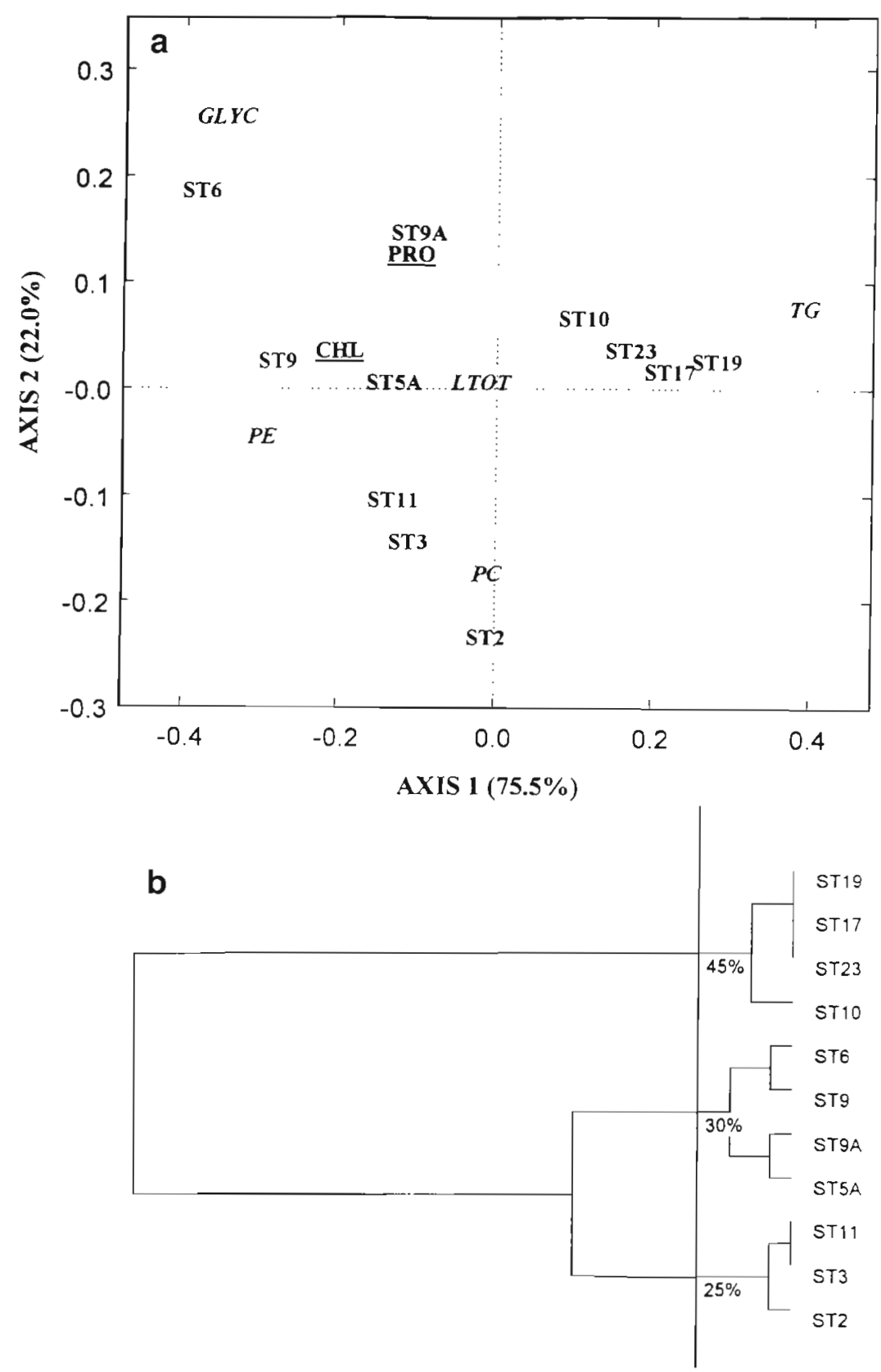

Fig. 5. Correspondence analysis of the spatial changes of total lipids and lipid classes of Euphausia superba collected during the FIBEX cruise. (a) Projection of biochemical descriptors and stations on the first 2 axes. Descriptors of the trophic environment (proteins and chlorophyll) projected on the factorial plane as supplementary variates. LTOT: total lipids; $P C$ : phosphatidyl choline; PE: phosphatidyl ethanolamine; GLYC: glycolipids; TG: triglycerides; CHL: chlorophyll; PRO: particulate proteins. For station (ST) locations refer to Fig. 1 (b) Dendrogram of hierarchical clustering of stations based on the scores on the first 5 factorial axes. \%: percent total variance accounted for by each cluster showed dry weights ranging from 9.6 to $43.4 \mathrm{mg}$, with no significant differences $(p<0.05)$. Lipid contents in both absolute and relative terms are presented in Table 4 , with the highest concentrations observed for the ovary in mature females and for the abdomen in 
Table 3. Euphausia superba. Mean ( \pm SD) size of individuals (mm) and dry weight $(\mathrm{mg})$ of the different body fractions and organs. $\mathrm{n}=$ number of individuals

\begin{tabular}{|c|c|c|c|c|}
\hline & \multirow[t]{2}{*}{ Subadults } & \multirow[t]{2}{*}{ Males } & \multicolumn{2}{|c|}{ Females } \\
\hline & & & Spent & Mature \\
\hline Mean size & $\begin{aligned} 41.9 & \pm 3.5 \\
\mathrm{n} & =5\end{aligned}$ & $\begin{array}{c}51.3 \pm 4.8 \\
n=9\end{array}$ & $\begin{array}{c}47.1 \pm 4.4 \\
n=12\end{array}$ & $\begin{aligned} 50.8 & \pm 4.3 \\
n & =10\end{aligned}$ \\
\hline \multicolumn{5}{|c|}{ Body fractions and organs } \\
\hline Abdomen & $83.2 \pm 24.3$ & $142 \pm 58$ & $98.8 \pm 30.2$ & $85.4 \pm 26.4$ \\
\hline Digestive gland & $9.6 \pm 4.3$ & $20.6 \pm 7.8$ & $20.2 \pm 11.2$ & $43.4 \pm 25.2$ \\
\hline \multicolumn{5}{|l|}{ Fraction including: } \\
\hline Gonads & $23.8 \pm 10.5$ & $33.6 \pm 37.2$ & $23.9 \pm 13.9$ & $175.3 \pm 63.2$ \\
\hline Fat body & $11.1 \pm 6.4$ & $30.4 \pm 18.9$ & $25.1 \pm 11.2$ & $32.9 \pm 8.3$ \\
\hline Stomach & $10.1 \pm 4.8$ & $22.1 \pm 14.4$ & $19.9 \pm 9.1$ & $22.8 \pm 7.8$ \\
\hline
\end{tabular}

triglyceride levels were recorded in abdomen tissues (mean: $28.7 \pm 2.1 \%$ ) in most stages, and in the fat body and stomach fractions of the subadults. Maximum percentages were observed in the other fractions for spent females and males (respective means: $42.2 \pm$ $1.7 \%$ and $38.6 \pm 1.8 \%$ ), as well as the fat body fraction in mature females and the gonad fraction in subadults. As anticipated, phosphatidyl choline (PC) displayed a reverse pattern with high levels in the abdomen of all the stages (mean: $47.6 \pm 1.8 \%$ ) and in the gonad fraction in mature females. Minimum percentages occurred in the

most stages. On a percent dry weight basis, the digestive gland displayed the largest lipid content in all stages except in mature females. The significance of these differences was tested by covariance analyses, which confirmed that changes in lipid content were related to the above stages ( $p>0.002)$ and organs $(p>$ $0.0001)$, and in absolute terms to size ( $p>0.0001)$. The ovary in mature females is very rich and contains about $60 \%$ of the total lipids, while in the other stages the abdomen contributes 30 to $40 \%$ to the total lipids, and the digestive gland accounts for 20 to $30 \%$. Fat body and stomach fractions were in all categories minor contributors, with respective ranges of 8 to $14 \%$ and 4 to $9 \%$ of the total lipids (Table 4 ).

Distribution of lipid classes among organs showed different patterns with stages (Tables 5 \& 6). Low fat body and stomach of males and mature females as well as the digestive gland and gonad fraction of subadults. Phosphatidyl ethanolamine (PE) showed maximum values in the abdomen (mean: $6.4 \pm 0.4 \%$ ) and minimum percentages in the gonad fraction (mean: $2.4 \pm 0.4 \%$ ). Glycolipids (GLY) showed low percentages in the abdomen (mean: $2.4 \pm 0.4 \%$ ), mainly in males and post spawn females, intermediate values in the digestive gland and gonad fraction (respective means: $3.7 \pm 0.4 \%$ and $3.0 \pm 0.4 \%$ ) and maximum values in the fat body and stomach fractions (respective means: $4.7 \pm 0.5 \%$ and $4.1 \pm 0.4 \%$ ). Monoglycerides (MAG) showed maximum values in the abdomen of most stages, except mature females. The variability in monoglycerides was significantly related to both stage and organ (ANOVA, p > 0.0003). Lysophosphatidyl

Table 4. Euphausia superba. Absolute (per mg) and relative (\% dry weight of each organ) lipid content ( \pm SD) of the different organs or tissue fractions and lipid distribution within body components (\% total lipid)

\begin{tabular}{|c|c|c|c|c|c|}
\hline \multirow[t]{2}{*}{ Body tissue and organs } & & \multirow[t]{2}{*}{ Subadults } & \multirow{2}{*}{ Males } & \multicolumn{2}{|c|}{ Females } \\
\hline & & & & Spent & Mature \\
\hline \multirow[t]{2}{*}{ Abdomen } & $\mathrm{mg}$ & $13.1 \pm 3.8$ & $15.2 \pm 6.4$ & $13.5 \pm 4.6$ & $1.3 \pm 4.2$ \\
\hline & $\because D W$ & $15.9 \pm 3.1$ & $11.2 \pm 2.5$ & $13.7 \pm 2.8$ & $13.5 \pm 3.9$ \\
\hline$\%$ total lipid located in tissue & & $40.8 \pm 1.6$ & $35.5 \pm 1.8$ & $30.9 \pm 1.3$ & $13.7 \pm 2.3$ \\
\hline \multirow[t]{2}{*}{ Digestive gland } & $\mathrm{mg}$ & $6.8 \pm 3.3$ & $14.1 \pm 5.6$ & $13.6 \pm 6.0$ & $10.4 \pm 5.1$ \\
\hline & $\% \mathrm{DW}$ & $52.7 \pm 7.8$ & $53.1 \pm 9.9$ & $46.2 \pm 11.0$ & $25.4 \pm 10.0$ \\
\hline$\%$ total lipid located in tissue & & $21.1 \pm 1.1$ & $32.9 \pm 1.3$ & $31.2 \pm 1.5$ & $12.7 \pm 2.8$ \\
\hline \multicolumn{6}{|l|}{ Fraction including: } \\
\hline \multirow[t]{2}{*}{ Gonads } & $\mathrm{mg}$ & $6.9 \pm 3.4$ & $4.6 \pm 1.7$ & $6.7 \pm 3.1$ & $49.8 \pm 16.0$ \\
\hline & $\%$ DW & $28.3 \pm 7.6$ & $26.1 \pm 6.7$ & $30.2 \pm 7.1$ & $31.3 \pm 7.6$ \\
\hline \multicolumn{2}{|l|}{$\%$ total lipid located in fraction } & $21.4 \pm 1.3$ & $10.7 \pm 2.3$ & $15.2 \pm 1.1$ & $60.5 \pm 1.8$ \\
\hline \multirow[t]{2}{*}{ Fat body } & $\mathrm{mg}$ & $2.9 \pm 2.7$ & $5.8 \pm 3.4$ & $5.9 \pm 2.6$ & $7.1 \pm 1.8$ \\
\hline & $\% \mathrm{DW}$ & $24.7 \pm 9.2$ & $22.5 \pm 4.1$ & $24.3 \pm 6.3$ & $21.9 \pm 4.6$ \\
\hline \multicolumn{2}{|l|}{$\%$ total lipid located in fraction } & $9.2 \pm 0.7$ & $13.5 \pm 1.9$ & $13.6 \pm 1.8$ & $8.6 \pm 0.7$ \\
\hline \multirow[t]{2}{*}{ Stomach } & $\mathrm{mg}$ & $2.4 \pm 1.6$ & $3.1 \pm 1.3$ & $3.9 \pm 1.2$ & $3.7 \pm 1.5$ \\
\hline & $\% \mathrm{DW}$ & $21.8 \pm 7.7$ & $20.2 \pm 6.6$ & $21.1 \pm 6.1$ & $16.1 \pm 4.0$ \\
\hline$\%$ total lipid located in fraction & & $7.4 \pm 0.5$ & $7.3 \pm 0.6$ & $9.0 \pm 0.9$ & $4.5 \pm 0.4$ \\
\hline
\end{tabular}


Table 5. Euphausia superba. Lipid classes composition for the different organs and tissue fractions of subadult and male stages. LPC: lysophosphatidyl choline; PC: phosphatidyl choline; PE: phosphatidyl ethanolamine; GLY: glycolipids; Chol: cholesterol; MAG: monoacylglycerols; TAG: triacylglycerols. Standard deviations are given in parentheses

\begin{tabular}{|c|c|c|c|c|c|c|c|c|c|c|c|c|c|c|}
\hline \multirow{2}{*}{$\begin{array}{l}\text { Body tissue } \\
\text { and organs } \\
\text { Abdomen }\end{array}$} & LPC & \multicolumn{5}{|c|}{ Subadults } & TAG & \multicolumn{7}{|c|}{ Males } \\
\hline & $\begin{array}{c}5.7 \\
(1.0)\end{array}$ & $\begin{array}{c}45.3 \\
(10.0)\end{array}$ & $\begin{array}{c}4.9 \\
(1.8)\end{array}$ & $\begin{array}{c}3.4 \\
(0.7)\end{array}$ & $\begin{array}{c}2.3 \\
(1.8)\end{array}$ & $\begin{array}{c}6.0 \\
(1.8)\end{array}$ & $\begin{array}{l}30.9 \\
(7.8)\end{array}$ & $\begin{array}{c}1.8 \\
(0.7)\end{array}$ & $\begin{array}{c}55.2 \\
(8.9)\end{array}$ & $\begin{array}{c}5.7 \\
(3.6)\end{array}$ & $\begin{array}{c}1.9 \\
(0.3)\end{array}$ & $\begin{array}{c}3.2 \\
(1.3)\end{array}$ & $\begin{array}{l}11.4 \\
(2.4)\end{array}$ & $\begin{array}{l}20.1 \\
(4.0)\end{array}$ \\
\hline Digestive gland & $\begin{array}{c}1.0 \\
(0.1)\end{array}$ & $\begin{array}{c}32.2 \\
(8.3)\end{array}$ & $\begin{array}{c}3.8 \\
(1.4)\end{array}$ & $\begin{array}{c}6.5 \\
\{3.5\}\end{array}$ & $\begin{array}{c}1.8 \\
(1.5)\end{array}$ & $\begin{array}{c}4.8 \\
(1.4)\end{array}$ & $\begin{array}{l}39.6 \\
(5.3)\end{array}$ & $\begin{array}{c}2.3 \\
(1.1)\end{array}$ & $\begin{array}{c}43.8 \\
(11.6)\end{array}$ & $\begin{array}{c}2.9 \\
(1.6)\end{array}$ & $\begin{array}{c}2.1 \\
(1.6)\end{array}$ & $\begin{array}{c}0.9 \\
(0.7)\end{array}$ & $\begin{array}{c}6.3 \\
(2.2)\end{array}$ & $\begin{array}{c}37.3 \\
(12.7)\end{array}$ \\
\hline \multicolumn{15}{|c|}{ Fraction including: } \\
\hline Gonads & $\begin{array}{c}3.0 \\
(2.4)\end{array}$ & $\begin{array}{l}30.3 \\
(7.0)\end{array}$ & $\begin{array}{c}1.9 \\
(1.4)\end{array}$ & $\begin{array}{c}2.1 \\
(1.3)\end{array}$ & $\begin{array}{c}3.0 \\
(1.9)\end{array}$ & $\begin{array}{c}6.5 \\
(3.2)\end{array}$ & $\begin{array}{l}51.0 \\
(6.0)\end{array}$ & $\begin{array}{c}0.9 \\
(0.8)\end{array}$ & $\begin{array}{c}46.6 \\
(20.5)\end{array}$ & $\begin{array}{c}1.7 \\
(1.0)\end{array}$ & $\begin{array}{c}2.4 \\
(2.0)\end{array}$ & $\begin{array}{c}2.0 \\
(1.8)\end{array}$ & $\begin{array}{c}3.0 \\
(3.0)\end{array}$ & $\begin{array}{c}43.2 \\
(18.9)\end{array}$ \\
\hline Fat body & $\begin{array}{c}6.1 \\
(1.3)\end{array}$ & $\begin{array}{l}50.5 \\
(7.2)\end{array}$ & $\begin{array}{c}3.8 \\
(1.8)\end{array}$ & $\begin{array}{c}4.9 \\
(5.7)\end{array}$ & $\begin{array}{c}1.5 \\
(1.1)\end{array}$ & $\begin{array}{c}1.8 \\
(3.6)\end{array}$ & $\begin{array}{l}29.1 \\
(5.4)\end{array}$ & $\begin{array}{c}1.6 \\
(1.2)\end{array}$ & $\begin{array}{l}34.9 \\
(9.8)\end{array}$ & $\begin{array}{c}3.4 \\
(1.7)\end{array}$ & $\begin{array}{c}2.9 \\
(2.6)\end{array}$ & $\begin{array}{c}2.3 \\
(1.4)\end{array}$ & $\begin{array}{c}9.4 \\
(1.8)\end{array}$ & $\begin{array}{c}44.0 \\
(18.1)\end{array}$ \\
\hline Stomach & $\begin{array}{c}5.5 \\
(2.6)\end{array}$ & $\begin{array}{l}38.7 \\
(8.1)\end{array}$ & $\begin{array}{c}4.4 \\
(2.1)\end{array}$ & $\begin{array}{c}4.1 \\
(2.7)\end{array}$ & $\begin{array}{c}2.3 \\
(2.1)\end{array}$ & $\begin{array}{c}2.8 \\
(2.3)\end{array}$ & $\begin{array}{c}35.2 \\
(16.3)\end{array}$ & $\begin{array}{c}2.6 \\
(1.8)\end{array}$ & $\begin{array}{c}36.8 \\
(9.9)\end{array}$ & $\begin{array}{c}3.5 \\
(2.3)\end{array}$ & $\begin{array}{c}3.2 \\
(1.8)\end{array}$ & $\begin{array}{c}2.1 \\
(2.3)\end{array}$ & $\begin{array}{c}5.3 \\
(3.2)\end{array}$ & $\begin{array}{c}46.3 \\
(11.7)\end{array}$ \\
\hline
\end{tabular}

Table 6. Euphausia superba. Lipid class composition for the different organs and tissue fractions of females at 2 maturity stages. Abbreviations as in Table 5. Standard deviations are given in parentheses. tr trace

\begin{tabular}{|c|c|c|c|c|c|c|c|c|c|c|c|c|c|c|}
\hline \multirow{3}{*}{$\begin{array}{l}\text { Body tissue } \\
\text { and organs } \\
\text { Abdomen }\end{array}$} & \multirow{3}{*}{$\begin{array}{l}\text { LPC } \\
3.2 \\
(1.2)\end{array}$} & \multicolumn{6}{|c|}{ Spent females } & \multicolumn{7}{|c|}{ Mature females } \\
\hline & & $\mathrm{PC}$ & $\mathrm{PE}$ & GLY & Chol & MAG & TAG & LPC & $\mathrm{PC}$ & \multicolumn{3}{|c|}{$\begin{array}{l}\text { PE GLY Chol } \\
\text { (\% total lipids })\end{array}$} & MAG & TAG \\
\hline & & $\begin{array}{c}45.2 \\
(7.9)\end{array}$ & $\begin{array}{l}8.0 \\
(2.4)\end{array}$ & $\begin{array}{c}1.2 \\
(0.7)\end{array}$ & $\begin{array}{c}3.3 \\
(1.2)\end{array}$ & $\begin{array}{c}6.7 \\
(2.3)\end{array}$ & $\begin{array}{l}32.4 \\
(9.4)\end{array}$ & $\begin{array}{c}4.8 \\
(2.0)\end{array}$ & $\begin{array}{c}42.7 \\
(10.2)\end{array}$ & $\begin{array}{c}7.2 \\
(1.3)\end{array}$ & $\begin{array}{c}3.1 \\
(1.0)\end{array}$ & $\begin{array}{l}5.0 \\
(1.5)\end{array}$ & $\begin{array}{l}2.7 \\
(2.3)\end{array}$ & $\begin{array}{l}32.2 \\
(8.1)\end{array}$ \\
\hline Digestive gland & $\begin{array}{l}4.1 \\
(1.8)\end{array}$ & $\begin{array}{l}37.8 \\
(8.1)\end{array}$ & $\begin{array}{c}4.3 \\
(2.4)\end{array}$ & $\begin{array}{c}2.6 \\
(0.6)\end{array}$ & $\begin{array}{c}1.3 \\
(1.0)\end{array}$ & $\begin{array}{l}4.0 \\
(1.9)\end{array}$ & $\begin{array}{c}42.6 \\
(10.2)\end{array}$ & $\begin{array}{l}2.3 \\
(2.1)\end{array}$ & $\begin{array}{c}43.8 \\
(11.6)\end{array}$ & $\begin{array}{c}2.9 \\
(1.6)\end{array}$ & $\begin{array}{c}2.1 \\
(1.6)\end{array}$ & $\begin{array}{c}0.9 \\
(0.8)\end{array}$ & $\begin{array}{l}6.3 \\
(2.2)\end{array}$ & $\begin{array}{r}37.3 \\
(12.8)\end{array}$ \\
\hline \multicolumn{15}{|c|}{ Fraction including: } \\
\hline Gonads & $\operatorname{tr}$ & $\begin{array}{l}40.2 \\
(6.9)\end{array}$ & $\begin{array}{l}3.3 \\
(1.3)\end{array}$ & $\begin{array}{c}0.6 \\
(0.2)\end{array}$ & $\begin{array}{l}2.2 \\
(1.6)\end{array}$ & $\begin{array}{c}4.3 \\
(3.3)\end{array}$ & $\begin{array}{l}49.5 \\
(7.8)\end{array}$ & $\begin{array}{c}1.9 \\
(1.8)\end{array}$ & $\begin{array}{l}53.9 \\
(7.8)\end{array}$ & $\begin{array}{l}3.4 \\
(1.6)\end{array}$ & $\begin{array}{c}6.3 \\
(4.4)\end{array}$ & $\begin{array}{l}3.0 \\
(1.0)\end{array}$ & $\begin{array}{l}2.7 \\
(1.7)\end{array}$ & $\begin{array}{l}26.7 \\
(8.8)\end{array}$ \\
\hline Fat body & $\begin{array}{c}1.9 \\
(1.8)\end{array}$ & $\begin{array}{l}35.6 \\
(7.2)\end{array}$ & $\begin{array}{c}4.6 \\
(1.6)\end{array}$ & $\begin{array}{c}2.8 \\
(1.0)\end{array}$ & $\begin{array}{c}1.8 \\
(0.8)\end{array}$ & $\begin{array}{l}6.1 \\
(1.7)\end{array}$ & $\begin{array}{c}43.6 \\
(11.9)\end{array}$ & $\begin{array}{l}3.5 \\
(1.6)\end{array}$ & $\begin{array}{l}35.1 \\
(5.5)\end{array}$ & $\begin{array}{c}4.6 \\
(1.5)\end{array}$ & $\begin{array}{c}3.3 \\
(1.7)\end{array}$ & $\begin{array}{l}2.5 \\
(0.8)\end{array}$ & $\begin{array}{c}3.1 \\
(0.3)\end{array}$ & $\begin{array}{l}44.3 \\
(5.1)\end{array}$ \\
\hline Stomach & $\begin{array}{c}3.8 \\
(2.5)\end{array}$ & $\begin{array}{l}35.1 \\
(4.2)\end{array}$ & $\begin{array}{c}4.0 \\
(2.1)\end{array}$ & $\begin{array}{c}4.9 \\
(2.7)\end{array}$ & $\begin{array}{c}2.6 \\
(1.2)\end{array}$ & $\begin{array}{c}5.8 \\
(3.2)\end{array}$ & $\begin{array}{l}42.7 \\
(5.9)\end{array}$ & $\begin{array}{c}3.9 \\
(0.9)\end{array}$ & $\begin{array}{l}38.0 \\
(5.7)\end{array}$ & $\begin{array}{c}6.0 \\
(3.2)\end{array}$ & $\begin{array}{c}4.3 \\
(2.5)\end{array}$ & $\begin{array}{c}4.4 \\
(1.1)\end{array}$ & $\begin{array}{c}1.4 \\
(1.2)\end{array}$ & $\begin{array}{l}39.2 \\
(9.8)\end{array}$ \\
\hline
\end{tabular}

choline (LPC) showed no significant changes (ANOVA, $p<0.05$ ).

The relationship between distribution of lipid classes, organs and stages can be more clearly described using a multivariate approach, i.e. PCA. Three factorial axes were needed to explain $83 \%$ of the total variance. Correlation between axes and lipid descriptors showed that the first axis was strongly related to the opposition between $\mathrm{PC}$ and triglycerides and accounted for $40.8 \%$ of the total inertia (Fig. 6). The second and third (not shown) axes accounted for $22.8 \%$ and $19.6 \%$ of the total variance (Fig. 6). They were respectively correlated to monoglycerides and PE for axis 2 and to glycolipids for axis 3 . Hierarchical clustering of the organs and stages (Fig, 6) suggested 2 major groupings, each associated with the dominance of 1 lipid descriptor: (1) high proportion of polar lipids ( $P C$ and $P E$ ) with the abdomen from all stages and the various fractions from mature females (except fat body), and most fractions from subadults (except gonad and digestive gland); (2) high proportion of the 2 acylglycerols (MAG and TAG) with mostly spent females and males, with digestive gland and fat body as representative body fractions. Within the polar lipid group, the cluster analysis also separated those organs and stages with high PC, low triglycerides and PE content lower than $4.5 \%$ (gonad and digestive gland from mature females and fat body from subadults) from those with lower PC, low triglycerides and PE content higher than $4.4 \%$ (abdomen from males, mature and post spawn females, and subadults; stomach from mature females and subadults) 

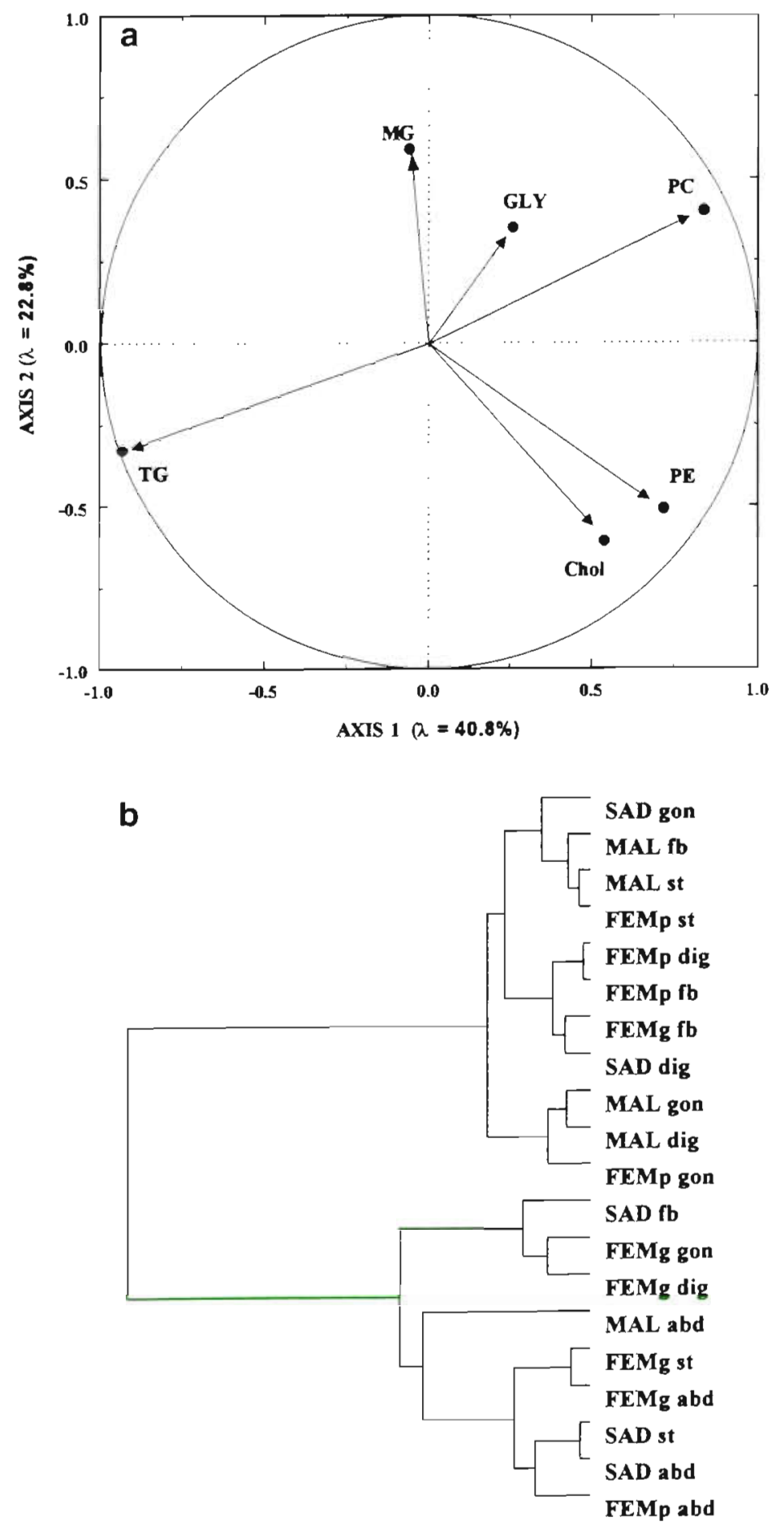

Fig. 6. Principal component analysis of the correlation matrix between the lipid classes in the different organs or body fractions of the main sexual and developmental stages of Euphausia superba. (a) Factor loadings on the first 2 axes ( $\lambda$ : \% total variance explained by each axis). PC: phosphatidyl choline; PE: phosphatidyl ethanolamine; GLY: glycolipids; MG: monoglycerides; TG: triglycerides; Chol: cholesterol. (b) Dendrogram of hierarchical clustering of organs for each stage based on the score on the first 5 axes. SAD: subadults; MAL: males; $\mathrm{FEM}_{\mathrm{p}}$ : post spawn females; $\mathrm{FEM}_{\mathrm{q}}$ : gravid (mature) females; gon gonads; fb: fat body; st: stomach; dig: digestive gland; abd: abdomen

\section{DISCUSSION}

The relation between wet weight and body length for the population sampled during FIBEX did not differ significantly from relations reported elsewere (Kato et al. 1982, Morris et al. 1988, Farber-Lorda 1994, Huntley et al. 1994). No significant differences were found between maturity stages, and a mean value of the allometric exponent $b$ of 3.12 was computed, suggesting isometric growth (i.e. body weight increasing with the cube of length).

Because body weight or size is not the main factor controlling lipid accumulation, the relationships between lipid content and size have been a matter of controversy. Hagen (1988) has illustrated that, for different locations, the variability in total lipid content can be so high that no relationship can be established. In the present work, a significant allometric relation was found for both total lipids and polar lipids in all maturity stages, and in subadults and females for triglycerides. A lower rate of accumulation was observed in males compared to females, and this decrease in triglyceride content in the Iarger males may be an illustration of the influence of mating activity as suggested by Virtue et al. (1996), assuming that, in the population sampled, larger males were sexually more active than smaller ones. In relative terms there were no significant relationships between weight corrected lipid content and size, as reported earlier by Clarke (1980).

Spatial variability in krill distribution has been the concern of several studies (e.g. Amos 1984, Brinton 1985, Trathan et al, 1993). Krill are abundant within the frontal zone and concentrated in meanders and eddies at boundaries between strong and weak flows of water (Sahrhage 1988). Changes in population structure may originate from passive advection of distinct populations or active migration to a more suitable area, or a combination of both. Residence time in a given area may also vary in relation to food supply or physiological or behavioural constraints. The area surveyed during FIBEX was located between $60^{\circ}$ and $64^{\circ} \mathrm{S}$ and centred on $40^{\circ} \mathrm{E}$. Its location was influenced by the Antarctic divergence, the mean position of which is between $65^{\circ}$ and $63^{\circ} \mathrm{S}$, depending on meteorological conditions (Lutjerharms et al. 1985, Miller \& Monteiro 1988, Park et al. 1991). North of the divergence (circumpolar current), the surface water flows towards the east, while to the south it flows in 
the opposite direction (Antarctic coastal current). As indicated by Deacon (1979) and Tchernia \& Janin (1980), the Antarctic divergence is not a well-localized front and produces multiple medium scale gyres. Data on temperature and salinity recorded during FIBEX showed doming isolines below $200 \mathrm{~m}$ along the $63^{\circ}$ and $64^{\circ} \mathrm{S}$ transects centred on $\mathrm{Stn} 5$, this was also the case at Stn 10 at $64^{\circ} \mathrm{S}$ and at Stns 17 and 13 at $63^{\circ} \mathrm{S}$, suggesting the possibility of 2 gyre systems (Simon 1983, 1986). The wind regime showed that the survey grid was located in the transition zone between westerly and easterly winds (Simon 1983), in agreement with the hypothesis that the Antarctic divergence was located between $64^{\circ}$ and $63^{\circ} \mathrm{S}$. Besides mesoscale circulation features, trophic conditions and residence time must also be considered to understand the spatial variability of biological descriptors like lipid content. Indeed, it has been suggested that triglyceride accumulation reflects the immediate nutritional history over periods of days to weeks (Håkanson 1984).

Site-to-site variability in lipid content has been reported by Pond et al. (1995) and related to both sexual maturity and surface water circulation. The grouping of stations found in the present study varied with the lipid descriptors considered: total lipid content resulted in 2 groups or areas (north/west versus south/central parts of the grid), while lipid classes + total lipids resulted in the discrimination of 3 areas (north, west/east and centre/south), each containing stations with similar concentrations of triglycerides or PC or PE. None of the local phytoplankton descriptors (chlorophyll and particulate protein) showed any relationship with total lipid content or depot fat of krill individuals, suggesting that residence time of the populations sampled was too short to establish stable trophic links with the local phytoplankton biomass. Within the areas corresponding to the factorial groups, krill lipid distribution resulted from complex interrelations between physical structure, changes in primary production, origin of populations and residence time in the area sampled. Indeed, because of the position of the divergence and the opposition in direction of the dominant currents between $63^{\circ}$ and $64^{\circ} \mathrm{S}$, a north-south separation could be anticipated. The east-west separation can also be understood with the 2 gyre systems which separated juvenile and subadult dominated populations (west) from adult dominated populations (east) (Gely 1983). Primary productivity data (Simon 1983) showed minimum values (40 to $75 \mathrm{mg} \mathrm{C} \mathrm{m}^{-2} \mathrm{~d}^{-1}$ ) at the extreme southeast (Stns 3 and 4) extreme southwest (Stn 11), maximum values (200 to $400 \mathrm{mg} \mathrm{C} \mathrm{m} \mathrm{m}^{-2} \mathrm{~d}^{-1}$ ) at the northern stations (Stns 2, 17, 18, 19 and 23) and intermediate values (130 to $250 \mathrm{mg} \mathrm{C} \mathrm{m}{ }^{-2} \mathrm{~d}^{-1}$ ) at the south-central stations (Stns 5 to 10). Thus, high triglyceride content was associated with high values of primary productivity (Stns 17, 18, 19 and 23), high phosphatidyl choline content apparently was related to those areas of minimum primary production or their immediate vicinity (Stns 2, 3 and 11) and high phosphatidyl ethanolamine content was associated with the area of medium primary productivity within the Antarctic divergence. A clear outlier was Stn 10, which showed better association with the northwestern grouping. This could be explained by a different origin, as suggested by the very different population structure (40\% subadults, $36 \%$ males and $24 \%$ females, compared to $30 \%$ subadults, $21 \%$ males and $49 \%$ females at neighboring $\operatorname{Stn} 9 \mathrm{~A}$ ).

Literature on the distribution of lipids in specific organs is limited to data from the abdominal muscle (Clarke 1980, Saether et al. 1985), the ovary (Clarke 1980), the digestive gland (Virtue et al. 1993a) or various body sections (Saether et al. 1985). Distribution of lipid classes among the 5 fractions and 4 developmental stages studied, showed (1) a lower percentage of triglycerides and higher percentage of phospholipids in the abdominal muscle of most stages and most organs (fat body excepted) of mature females and (2) maximum percentages of triglycerides in the other fractions for spent females and in the fat body fraction of the other stages. The high lipid levels found in the digestive gland of immature stages (46 to $53 \%$ tissue dry weight) and in the ovaries of mature females (31\% tissue dry weight) support the theory that lipids accumulate in the digestive gland for energetic purposes or transfer to the ovary for spawning (Dall et al. 1992, Virtue et al. 1993b). The contribution of the different organs to the total lipid pool reported by Clarke (1980) was highest for the ovary $(60 \%)$, minimal for the digestive gland $(1.8 \%)$ and intermediate for the reminder of the fractions analyzed (36\%). The presence of significant percentages of lysophosphatidyl choline (LPC) in all fractions was puzzling, mainly in view of the absence of free fatty acids. Indeed, if LPC resulted from the degradation of PC, a pool of free fatty acids would be expected. The possibility that LPC could be in fact an intermediary product in the synthesis of PC should be considered.

The possible contribution of the eyes' lipids to the fraction containing the stomach was considered. Bell \& Dick (1990) and Navarro et al. (1992) reported lipid composition of marine Crustacea eyes and showed a dominance of PC (43\% polar lipids), PE (32\% polar lipids) and phosphatidyl inositol. ( $9 \%$ polar lipids). The generally low levels of PE compared to PC in the stomach fraction strongly suggest that eye lipids made a small (if any) contribution to the fraction.

The potential regulatory function of the fat body in euphausiids is largely unknown but, from the large 
database on crustaceans and insects (see Tom et al. 1987, Suzuki et al. 1989, Candy et al. 1997), it could be associated with reproduction (vitellogenesis) and/or locomotion. During vitellogenesis, decapods draw their yolk lipids from the digestive gland. This results in an inverse relationship between the lipid content of the fat body (or the ovary) and that of the digestive gland (Adiyodi \& Subramonian 1983). The lack of such a relationship in our data illustrates that the digestive gland may not be the only source of lipids during vitellogenesis. In arthropods, muscles do not store lipids, and prolonged aerobic metabolism must be fueled by an input of acylglycerols, which are converted from triglycerides in the fat body (Candy et al. 1997. Haunerland 1997). The opposing levels of triglycerides between the abdominal muscles and the fat body, reported above, suggest that adult stages of Euphausia superba may adopt a similar metabolic strategy. Though purely hypothetical, the comparison between energy expenditure of swimming E. superba and flying insects should be viewed in the context of the energy expenditure of a strong swimmer like $E$. superba (15 to $20 \mathrm{~cm} \mathrm{~s}^{-1}$; Hamner 1984) moving in sea water, an environment with a molecular viscosity $10^{3}$ to $10^{4}$ higher than that of air (Hasse \& Dobson 1983).

Since the early work of Ellingsen (1982), the covariation of PC and total lipids in euphausiids has been confirmed by several studies (Saether et al. 1985, 1986. Hagen 1988, Hagen et al. 1996, Mayzaud 1997). Seather et al. (1986) assumed that both neutral and polar lipids are laid down and utilized when krill lipid reserves are accumulated or depleted. Hagen (1988) and Hagen et al. (1996) indicated that triglycerides are the primary depot fat and are deposited at a faster rate than phospholipids. In the present study the opposite trend was observed. More important, rates of deposition appear to vary with sex and growth stage, with polar lipids deposited faster than (male and spent females) or at a similar rate to (subadults and mature females) triglycerides. Hagen et al. (1996) further hypothesized that PC is more easily mobilized than neutral lipids and proposed that such an accumulation probably plays a major role in the winter survival strategy of Euphausia superba. This conclusion, derived from field data, is in conflict with the experimental results on long term starvation reported by Ikeda \& Dixon (1982) and Virtue et al. (1997). In both cases, lipids could not be the primary energy source accounting for catabolic activity during these periods of starvation in these studies. Only the initial $5 \mathrm{~d}$ resulted in a significant catabolism of polar lipids which matched the daily energy expenditure (assuming a mean respiration rate of $100 \mu \mathrm{O}_{2}$ ind. $^{-1} \mathrm{~d}^{-1}$ for adults; Opalinski 1991). If polar lipids were the primary energy source (triglycerides did not vary significantly), the content of polyunsaturated fatty acids (20:5 13 and 22:6w3) should have fallen significantly, which is contrary to the constant levels reported by Virtue et al. (1997). The higher slope between polar lipids and total lipids in subadults and triglyceride depleted males compared to females (mature and spent) further suggests that the individual with the largest energy needs was also the one with the highest PC catabolism. More likely, the preference for $\mathrm{PC}$ catabolism is probably related to a specific function which cannot be fulfilled by triglycerides. An example would be the supply of essential nutrients, such as organic phosphorus, choline and/or essential fatty acids, under unfavorable trophic conditions. At this stage there is no valid conclusion on the role of $\mathrm{PC}$ in euphausiids and further metabolic studies are needed.

Acknowledgements. We are very grateful to J. Chiaverini and M. Guay, who helped with the laboratory analyses. Our thanks also go to the officers and the crew of the NO 'Marion Dufresne' for their assistance at sea during the BIOMASS cruises. Work was supported by TAAF, IFRTP and INSUCNRS. Editorial and scientific comments by Dr P. Virtue improved the manuscript.

\section{LITERATURE CITED}

Ackman RG (1981) Application of flame ionization detector to thin layer chromatography on coated quartz rods. Methods Enzymol 72:205-252

Adiyodi RG, Subramonian T (1983) Arthropoda-Crustacea. In: Adiyodi KG, Adiyodi RG (eds) Reproductive biology of invertebrates, Vol 1. Oogenesis, oviposition and oosorption. John Wiley and Sons, Toronto, p 443-495

Amos AF (1984) Distribution of krill (Euphausia superba) and the hydrography of the southern ocean: large-scale processes. J Crustac Biol 4:306-329

Barnes H, Blackstock J (1973) Estimation of lipids in marine animals and tissues: detailed investigation of the sulphovanilin method for total lipids. J Exp Mar Biol Ecol 12: $103-118$

Bell MV, Dick JR (1990) The fatty acid composition of phospholipids from the eyes of the northern deep water prawn Pandalus borealis. Biochem Soc Trans 18:907-908

Benzecri JP (1969) Statistical analysis as a tool to make patterns emerge from data. In: Watanabe S (ed) Methodology of pattern recognition. Academic Press, New York, p 35-74

Bligh EG, Dyer WJ (1959) A rapid method of total lipid extraction and purification. Can J Biochem Physiol 37:911-917

Bottuno NR (1974) The fatty acids of the Antarctic phytoplankton and euphausiids. Fatty acid exchange among trophic levels of the Ross Sea. Mar Biol 27:197-204

Brinton $E$ (1985) The oceanographic structure of the eastern Scotia Sea-III. Distributions of euphausiid species and their developmental stages in 1981 in relation to hydrography. Deep-Sea Res 32:1153-1180

Candy DJ, Becker A, Wegener G (1997) Coordination and integration of metabolism in insect flight. Comp Biochem Physiol 117B:497-512

Clark A. (1980) The biochemical composition of krill Euphausia superba Dana from south Georgia. J Exp Mar Biol Ecol 43:221-236 
Clark A (1984) Lipid content and composition of Antarctic krill Euphausia superba Dana. J Crustac Biol 4:285-294

Cuzin-Roudy J (1987) Gonad history of the Antarctic krill Euphausia superba Dana during its breeding season. Polar Biol 7:237-244

Cuzin-Roudy J (1993) Reproductive strategies of the Mediterranean krill Meganyctiphanes norvegica and the Antarctic krill Euphausia superba (Crustacea:Euphausiacea). Invertebr Reprod Dev 23:105-114

Cuzin-Roudy J, Amsler MO (1991) Ovarian development and sexual maturity staging in Antarctic krill Euphausia superba Dana (Euphausiacea). J Crustac Biol 11:236-249

Dall W, Chandumpai A, Smith DM (1992) Fatty acid composition of organs and tissues of the tiger prawn Penaeus esculentus during the moulting cycle and during starvation. Mar Biol 113:45-55

Deacon GER (1979) The Weddel gyre. Deep-Sea Res 26: 981-995

Ellingsen TE (1982) Biokjemiske studier over Antarkisk krill. Dr Engineer thesis, University of Trondheim

Farber-Lorda J (1994) Length-weight relationships and coetficient of condition of Euphausia superba and Thysanoessa macrura (Crustacea: Euphausiacea) in the southwest Indian Ocean during summer. Mar Biol 118:645-650

Fraser AJ, Gamble JC, Sargent JR (1988) Changes in lipid content, lipid class composition and fatty acid composition of developing eggs and unfed larvae of cod (Gadus morhual. Mar Biol 99:307-313

Gely C (1983) Contribution à l'étude du krill Euphausia superba (Dana). Essai d'évaluation de la production secondaire et étude des populations échantillonées pendant la campagne MD25/FIBEX. Thèse de Doctorat 3ème cycle, Université Pierre et Marie Curie (Paris 6)

Gower JC (1987) Introduction to ordination techniques. In: Legendre P, Legendre L (eds) Developments in numerical ecology. NATO A.SI Series G14:3-64

Hagen W (1988) On the significance of lipids in Antarctic zooplankton. Berichte fur Polarforsch 49:92-117 (CFAS translation \# 5458)

Hagen W, Van Vleet ES, Kattner G (1996) Seasonal storage as overwintering strategy of Antarctic krill. Mar Ecol Prog Ser 134:85-89

Håkanson JL (1984) The long and short term feeding conditions in field caught Calanus finmarchicus as determined by the lipid content. Limnol Oceanogr 29:794-804

Hamner WM (1984) Aspects of schooling of Euphausia superba. J Crustac Biol 4:67-74

Hasse L, Dobson F (1983) Introductory physics of the atmosphere and ocean. Reidel Publishing Co, Boston

Haunerland NH (1997) Transport and utilization of lipids in insect flight muscle. Comp Biochem Physiol 117B:475-482

Hirayama O, Morita K (1980) A simple and sensitive method for the quantitative analysis of chloroplast lipids by use of thin layer chromatography and flame ionization detector. Agric Biol Chem 44:2217-2219

Huntley ME, Nordhausen W, Lopez MDG (1994) Elemental composition, metabolic activity and growth of Antarctic krill Euphausia superba during winter. Mar Ecol Prog Ser $107: 23-40$

Ikeda T, Dixon P (1982) Body shrinkage as a possible overwintering mechanism of the Antarctic krill Euphausia superba Dana. J Exp Mar Biol Ecol 62:143-151

Kato M, Segawa S, Tanoue E, Murano M (1982) Filtering and ingestion rates of the Antarctic krill Euphausia superba Dana. Trans Tokyo Univ Fish 5:167-175

Kolokowska A (1991) The influence of sex and maturity stage of krill (Euphausia superba Dana) upon the content and composition of its lipids. Pol Polar Res 12:73-78

Lebart L, Morineau A. Piron M (1995) Statistique exploratoire multidimensionnelle. Dunod, Paris

Lutjerharms JRE, Walters NM, Allanson BR (1985) Oceanic frontal systems and biological enhancement. In: Siegfried WR, Condy PR, Laws RM (eds) Antarctic nutrient cycles and food webs. Springer-Verlag, Berlin, p 11-21

Makarov RR, Denys CJ (1980) Stages of sexual maturity of Euphausia superba Dana. Biomass Handb 11:1-11

Mauchline J (1980) The biology of mysids and euphausiids Adv Mar Biol 18:1-681

Mayzaud P (1997) Spatial and life cycle changes in lipid and fatty acid structure of the Antarctic euphausid Euphausia superba. In: Battaglia B, Valencia J, Walton DWH (eds) Antarctic communities. Cambridge University Press, Cambridge, p 284-294

Mayzaud P, Chanut JP, Ackman RG (1989) Seasonal changes of the blochemical composition of marine particulate matter with special reference to fatty acids and sterols. Mar Ecol Prog Ser 56:189-204

Mayzaud P, Farber-Lorda J, Corre MC (1985) Aspects of the nutritional metabolism of two euphausiids: Euphausia superba and Thysanoessa macrura. In: Siegfried WR, Condy PR, Laws RM (eds) Antarctic nutrient cycles and food webs. Springer-Verlag, Berlin, p 330-338

Miller CB, Morgan CA, Prahl FG, Sparrow MA (1998) Storage lipids of the copepod Calanus finmarchicus from the George Bank and the Gulf of Maine. Limnol Oceanogr 43:488-497

Miller DGM, Monteiro PMS (1988) Variability in the physical and biotic environment of the Antarctic krill (Euphausia superba), South Africa: some results and a conceptual appraisal of important interactions. In: Sahrhage D (ed) Antarctic Ocean and resources variability. Springer-Verlag, Berlin, p 245-257

Morris DJ, Watkins JL, Ricketts C, Buchholz F, Priddle J (1988) An assessment of the merits of length and weight measurements of Antarctic krill Euphausia superba. Br Antarct Surv Bull 79:27-50

Navarro JC, Bell MV, Amat F, Sargent JR (1992) The fatty acid composition of phospholipids from brine shrimp, Artemia sp, eyes. Comp Biochem Physiol 103B:89-91

Opalinski KW (1991) Respiratory metabolism and metabolic adaptations of Antarctic krill Euphausia superba. Pol Arch Hydrobiol 38:183-263

Park Y, Gamberoni L, Charriaud E (1991) Frontal structure and transport of the Antarctic circumpolar current in the South Indian Ocean sector, 40-80 E. Mar Chem 35:45-62

Pond DW, Watkins JL, Priddle J, Sargent JR (1995) Variation in the lipid content and composition of Antarctic krill (Euphausia superba) at South Georgia. Mar Ecol Prog Ser 117:49-57

Quetin LB, Ross RM (1991) Behavioural and physiological characteristics of the Antarctic krill Euphausia superba. Am Zool 31:49-63

Quetin LB, Ross RM, Clarke A (1994) Krill energetics: seasonal and environmental aspects of the physiology of Euphausla superba. In: El Sayed SZ (ed) Southern Ocean ecology, the BIOMASS prospective. Cambridge University Press, Cambridge, p 165-184

Reinhardt SB, Van Vleet ES (1986) Lipid composition of twenty-two species of Antarctic midwater zooplankton and fish. Mar Biol 91:149-159

Ross RM, Quetin LB (1986) How productive are Antarctic krill? BioSci 36:264-269

Saether O, Ellingsen TE, Mohr V (1985) The distribution of lipids in the tissues of Antarctic krill Euphausia superba. Comp Biochem Physiol 81B:609-614 
Saether O, Ellingsen TE, Mohr V (1986) Lipids of North Atlantic krill. J Lipid Res 27:274-285

Sahrhage D (1988) Some indications for environmental and krill resources variability in the Southern ocean. In: Sahrhage D (ed) Antarctic Ocean and resources variability. Springer-Verlag, Berlin, p 33-40

Shantha NC, Ackman RG (1990) Advantage of total lipid hydrogenation prior to lipid class determination on chromarod SIII. Lipids 25:570-574

Simon V (1983) Assimilation et régénération des sels nutritifs dans l'océan autral: caractérisation et relation avec la structure hydrologique. Thèse de Doctorat, Université Aix Marseille II

Simon V (1986) Le système assimilation-régénération des sels nutritifs dans les eaux superficielles de l'océan Austral. Mar Biol 92:431-442

Sokal RR, Rohlf FJ (1981) Biometry. Freeman and Co, New York

Stahl E (1969) Thin layer chromatography. A laboratory handbook. Springer-Verlag, Berlin

Suzuki S, Yamasaki K, Katakura Y (1989) Vitellogenin synthesis by fat body and ovary in the terrestrial isopod, Armadillidium vulgare. Gen Comp Endocrinol 74:120-126

Tchernia P, Janin PF (1980) Observations of the Antarctic East-Wind drift using tabular iceberg tracked by satellite Nimbus F (1975-1977). Deep-Sea Res 27:467-474

Editorial responsibility: Otto Kinne (Editor),

Oldendorf/Luhe, Germany
Tom M, Goren M, Ovadia M (1987) Localization of the vitellin and its possible precursors in various organs of Parapenaeus longirostris (Crustacea, Decapoda, Penaeidae). Int J Invertebr Reprod Develop 12:1-12

Trathan PN, Priddle J, Watkins JL, Miller DGM, Murray AWA (1993) Spatial variability of Antarctic krill in relation to mesoscale hydrography. Mar Ecol Prog Ser 98:61-71

Virtue P, Nichols PD, Nicol S (1997) Dietary-related mechanisms of survival in Euphausia superba: biochemical changes during long-term starvation and bacteria as a possible source of nutrition. In: Battaglia B, Valencia $J$, Walton DWH (eds) Antarctic communities. Cambridge University Press, Cambridge, p 193-201

Virtue P, Nichols PD, Nicol S, Hosie G (1996) Reproductive trade-off in male Antarctic krill, Euphausia superba. Mar Biol 126:521-527

Virtue P, Nichols PD, Nicol S, McMinn A, Sikes EL (1993a) The lipid composition of Euphausia superba Dana in relation to the nutritional value of Phaeocyctis pouchetii (Hariot) Lagerheim. Antarct Sci 5:169-177

Virtue P, Nicol S, Nichols PD (1993b) Changes in the digestive gland of Euphausia superba during short term starvation: lipid classes, fatty acid and sterol content and composition. Mar Biol 117:441-448

Wilkinson L (1996) Systat for Windows: statistics. SPSS Inc, New York

Submitted: January 16, 1998; Accepted: July 24, 1998

Proofs received from author(s): October 15, 1998 